\title{
Effect of treatment on physiological responses to exercise in East African industrial workers with iron deficiency anaemia
}

\author{
C. T. M. DAVIES and J. P. M. VAN HAAREN \\ MRC Environmental Physiology Unit, London School of Hygiene and Tropical Medicine, \\ Keppel Street, London WC1 \\ and \\ The Group Occupational Health Service, Dar es Salaam, Tanzania
}

\begin{abstract}
Davies, C. T. M., and van Haaren, J. P. M. (1973). British Journal of Industrial Medicine, 30, 335-340. Effect of treatment on physiological responses to exercise in East African industrial workers with iron deficiency anaemia. The physiological responses to exercise on an upright bicycle ergometer have been investigated in groups of anaemic (mean $\mathrm{Hb}=7.8 \mathrm{~g} / 100 \mathrm{ml}$ ) and control (mean $\mathrm{Hb}=13.7 \mathrm{~g} / 100 \mathrm{ml}$ ) East African industrial workers before and after treatment with oral iron (Fe $200 \mathrm{mg}$ ) tablets and on a third group of anaemic subjects (mean $=7.4 \mathrm{~g} / 100 \mathrm{ml}$ ) who received no treatment.

Before treatment anaemic subjects exercised with an increased cardiac frequency at a fixed oxygen intake $\left(\mathrm{V}_{2}\right)$ of $1.51 / \mathrm{min}$ and a marked reduction in predicted maximum aerobic power output when compared to normal controls. The effect of therapy was to reverse these changes so that no significant differences existed between the two treatment groups but both were significantly different from their anaemic controls. The pulmonary minute ventilation at a $\dot{\mathrm{Vo}}_{2}$ of $1.51 / \mathrm{min}$ and the $\mathrm{Vo}_{2}$ at a work load of $8820 \mathrm{Nm} / \mathrm{min}$ $(900 \mathrm{kpm} / \mathrm{min})$ were similar in all three groups of subjects and remained constant throughout the experimental investigation. The findings carry important implications for those engaged in industrial medicine in developing countries and show clearly that the debilitating effects of iron deficiency anaemia can be rapidly eliminated by simple and inexpensive therapy in factory workers without seriously disturbing their normal work routine.
\end{abstract}

Anaemia is accompanied by changes in the haemodynamic responses to exercise in man (Sproule, Mitchell, and Miller, 1960; Duke and Abelmann, 1969; Davies, Chukweumeka, and van Haaren, 1973) and in a reduction in maximum aerobic power output (Davies, Chukweumeka, and van Haaren, 1973). The effect of treatment of anaemia on these physiological responses to work is less well documented. Further, compared to the studies at rest, which uniformly show that the disturbances to the cardiorespiratory system due to the anaemia can be rapidly reversed by therapy (Brannon, Merrill, Warren, and Stead, 1945; Backman, 1961; Roy, Bhatia, Mathur, and Virmani, 1963; Duke and Abelmann, 1969) the evidence from the exercise studies available is conflicting. For instance, Andersen and Barkve (1970) show in five patients that the cardiac response and oxygen cost of exercise are reduced following treatment, but both Beutler, Larsh, and Tanzi (1960) and Cotes et al. 
(1972) show no consistent changes in either exercise tolerance or the cardiorespiratory adaptations to work after therapy. Indeed, Beutler and his co-workers go further and suggest that the symptoms of iron deficiency may arise from mechanisms other than a generalized defect in the $\mathrm{O}_{2}$ transporting system.

In the present study we have investigated the physiological responses to exercise before and after iron therapy in 22 male adult African industrial workers. A preliminary report of this work has been given (Davies and van Haaren, 1973).

\section{Subjects}

The subjects were young adult Africans aged 18 to 35 years living and working in Dar es Salaam, Tanzania. They were identified during a large industrial survey of iron deficiency anaemia (Figure) and subsequently their history was taken and a medical examination performed. Only those subjects who were free from clinical signs of disease, other than the anaemia, were included in the investigation. The design of the experiment was explained to each subject and his consent to take part was obtained.

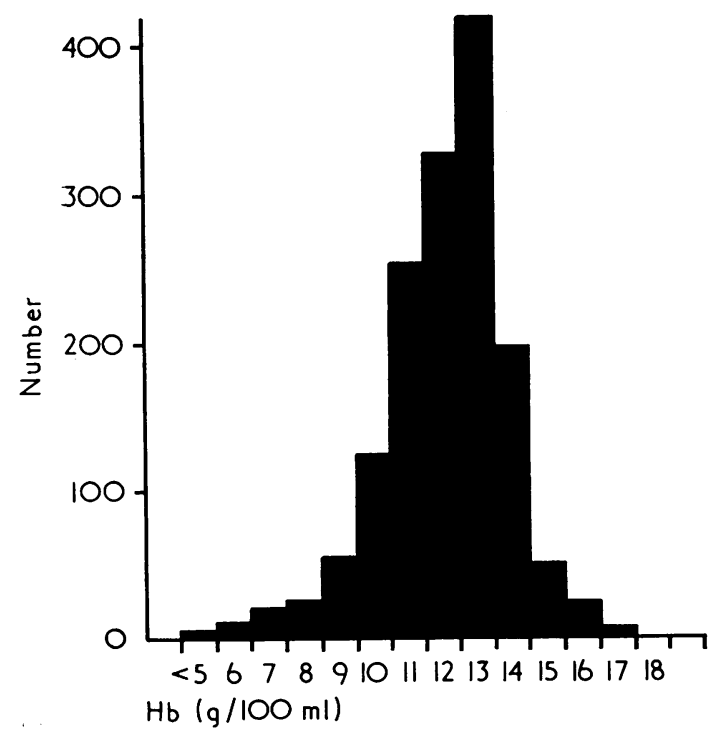

FIGURE. Histogram showing distribution of circulating haemoglobin concentration $(\mathrm{g} / 100 \mathrm{ml})$ in a survey of industrial workers in Dar es Salaam from whom the subjects of the present investigation were selected. It will be noted that $15 \%$ of the industrial population of Dar es Salaam have $\mathrm{Hb}$ levels below $10 \mathrm{~g} / 100 \mathrm{ml}$ and $50 \%$ have values below $12 \mathrm{~g} / 100 \mathrm{ml}$, the recommended lower limit for normal healthy subjects by the World Health Organization (1959).
The study was originally made up of 30 subjects who were divided into two groups, normal controls with $\mathrm{Hb}>11.5$ $\mathrm{g} / 100 \mathrm{ml}$ and anaemic test subjects with $\mathrm{Hb}<8.5 \mathrm{~g} / 100 \mathrm{ml}$. They reported to the laboratory on two separate occasions. On the first visit their responses to exercise were measured: then the test subjects and the normal controls were given daily treatment over a period of approximately three months with tablets containing ferrous sulphate, $200 \mathrm{mg}$ per day. The treatment was supervised each day by the medical assistants at the subjects' factories and a record was kept of attendance.

Of the original 30 subjects taking part in the investigation six normal controls and two anaemic test subjects failed to complete the course of treatment. In addition, five anaemic subjects failed to report for treatment at all, although they were persuaded to attend the laboratory again after three months for their response to exercises to be measured again. Thus, three rather than the original two groupings have been used in this analysis: group 1anaemic test subjects $(n=8)$, group II-normal controls $(n=9)$; and group III-anaemic controls $(n=5)$.

\section{Methods}

Details of the methods used to measure the subjects during exercise have been previously given (Davies et al., 1973) and only brief outlines of involved procedures will be given here.

Exercise was performed on a Monark (upright) ergometer. Each subject was allowed to practise and perform the work test on one occasion before definitive measurements of exercise performance were made in an attempt to overcome the problem of habituation to bicycling, as described by Davies, Tuxworth, and Young (1970).

The subjects were required to exercise at five consecutive work loads, the work load being raised by $1470 \mathrm{Nm} /$ $\min (150 \mathrm{kpm} / \mathrm{min})$ every two minutes. During the final minute of each work load ventilation minute volume (by Parkinson-Cowan CD4 dry gas meter) and cardiac frequency (from a standard Philips cardiograph) were recorded, and expired air was collected from a mixing chamber for subsequent analysis.

In 8 of the 22 subjects, expired air was analysed for $\mathrm{O}_{2}$ and $\mathrm{CO}_{2}$ content using a paramagnetic $\mathrm{O}_{2}$ analyser (Servomax Ltd.) and a Katharometer (Cambridge Instruments $\mathrm{Ltd}$.) respectively, and oxygen intake $\left(\dot{\mathrm{VO}}_{2}\right)$ was calculated in the usual way. However, in the remaining 14 subjects $\mathrm{CO}_{2}$ content was not measured and $\dot{\mathrm{Vo}}_{2}$ was estimated from minute ventilation volume and $\mathrm{O}_{2}$ content using the Weir (1949) formula and a standard calorific value for oxygen of $21.0 \mathrm{~kJ} /$ litre $(5 \mathrm{kcal} / \mathrm{litre})$. This method of calculating $\dot{\mathrm{V}}_{2}$ is likely to introduce an additional $2 \%$ error (Passmore and Draper, 1963) into energy expenditure measurements and should be borne in mind when interpreting our results. Individual regression lines were fitted to the $\dot{\mathrm{VO}}_{2}$, minute ventilation $\left(\dot{\mathrm{V}}_{\mathrm{E}}\right)$, and cardiac frequency $\left(f_{H}\right)$ data which enabled $\dot{V}_{E}$ and $f_{H}$ to be expressed in terms of a given $\dot{V O}_{2}$ of $1.51 / \mathrm{min}$ ( $\dot{V}_{E} 1.5$ and $\left.f_{H} 1 \cdot 5\right)$ (Cotes et al., 1969).

Similarly, regression of $\dot{V}_{2}$ on work output ( $(\dot{W})$ and $\mathrm{Vo}_{2}$ on $\mathrm{f}_{\mathrm{H}}$ were calculated for each subject and from these equations $\dot{V}_{2}$ was expressed at a given $\dot{W}$ of $8820 \mathrm{Nm} / \mathrm{min}(900 \mathrm{kpm} / \mathrm{min})\left(\mathrm{Vo}_{2}, 900\right)$ and maximum 
aerobic power output $\left(\dot{\mathrm{V}}_{2 \mathrm{max}}\right)$ was predicted by extrapolation of the $\dot{V O}_{2} / f_{H}$ curve to an assumed $f_{\mathrm{H} \text { max }}$ of 195 (Davies, 1968; Ojikutu, Fox, Davies, and Davies, 1972).

In addition, weight and the skinfold thickness at four sites (biceps, triceps, subscapular, and suprailiac) were measured, from which lean body mass (LBM) was calculated after the method of Durnin and Rahaman (1967). Blood haemoglobin concentration was measured by the cyanmethaemoglobin method. Duplicate measurements were required to agree within $\pm 0.5 \mathrm{~g} / 100 \mathrm{ml}$.

\section{Results}

The physical characteristics of the test and control subjects are given in Table 1 . The test subjects are slightly lighter in weight, shorter in stature, and have less body fat than the normal controls, but none of the differences shown in Table 1 except for circulating blood haemoglobin reaches conventional levels of significance.

The responses to exercise before treatment are summarized in Table 2. They show that for a fixed work load of $8820 \mathrm{Nm} / \mathrm{min}(900 \mathrm{kpm} / \mathrm{min})$ there is no significant difference in $\dot{\mathrm{Vo}}_{2}$ between the three groups. This is also true for minute ventilation $\left(\dot{V}_{E_{1.5}}\right)$, but there is a marked tendency towards higher mean values in the two anaemic groups (Davies et al., 1973). The cardiac frequency at $\mathrm{VO}_{2}$ of $1.5 \mathrm{l} / \mathrm{min}\left(\mathrm{f}_{\mathrm{H}_{1.5}}\right)$ is significantly lower $(\mathrm{P}<0.05)$ and the predicted maximum aerobic power $\left(\dot{\mathrm{V}}_{2} \max \right)$ is significantly higher $(P<0.05)$ in the normal controls compared with the two anaemic groups.

\section{Effects of treatment}

Following treatment with oral iron tablets (Fe $200 \mathrm{mg}$ ), there is a marked and significant increase $(+5.6 \mathrm{~g} / 100 \mathrm{ml} P<0.001)$; in blood haemoglobin in the test subjects, the haemoglobin of the two control groups remaining unchanged. The mean changes in the physiological responses to exercise (Table 3) show that the major effect of treatment was a marked and significant decrease $(-23$ beats $/ \min (P<0.001))$ of $f_{H}{ }_{1.5}$ in test subjects compared to the normal $(-1$ beat $/ \mathrm{min})$ and anaemic controls $(-7$ beats $/ \mathrm{min})$. There was

\section{TABLE 1}

Physical Characteristics of Subjects: Age, Weight, Height, the Sum of 4 Skinfold ThickNesses (Biceps, Triceps, Subscapular, and Suprailiac), Lean Body Mass, Calculated from Skinfold Thicknesses after the Method of Durnin and Rahaman (1967), and Circulating BLOOD HAEMOGLOBIN

\begin{tabular}{|c|c|c|c|c|c|c|}
\hline Group & $\begin{array}{l}\text { Age } \\
(y r)\end{array}$ & $\begin{array}{c}W t \\
(k g)\end{array}$ & $\begin{array}{c}\mathrm{Ht} \\
(\mathrm{cm})\end{array}$ & $\sum_{(m m)} s f$ & $\begin{array}{c}L B M \\
(k g)\end{array}$ & $\stackrel{H b}{(g / 100 ~ m l)}$ \\
\hline $\begin{array}{l}\text { Test subjects } I \\
(\mathrm{n}=8)\end{array}$ & $\begin{array}{r}22 \cdot 0 \\
\pm 6 \cdot 3\end{array}$ & $\begin{array}{r}50 \cdot 3 \\
\pm 5 \cdot 1\end{array}$ & $\begin{array}{l}162 \cdot 1 \\
\pm 4 \cdot 5\end{array}$ & $\begin{array}{r}20 \cdot 4 \\
\pm 2 \cdot 8\end{array}$ & $\begin{array}{r}45 \cdot 8 \\
\pm 4 \cdot 3\end{array}$ & $\begin{array}{r}7 \cdot 8 \\
\pm 1 \cdot 2\end{array}$ \\
\hline $\begin{array}{l}\text { Normal controls II } \\
(n=9)\end{array}$ & $\begin{array}{r}26 \cdot 0 \\
\pm 3 \cdot 5\end{array}$ & $\begin{array}{r}56 \cdot 3 \\
\pm 8 \cdot 8\end{array}$ & $\begin{array}{l}165 \cdot 4 \\
\pm 5 \cdot 7\end{array}$ & $\begin{array}{r}24 \cdot 3 \\
\pm 6 \cdot 5\end{array}$ & $\begin{array}{r}50 \cdot 2 \\
\pm 7 \cdot 9\end{array}$ & $\begin{array}{l}13 \cdot 7^{* * *} \text { II, III } \\
\pm 1 \cdot 1\end{array}$ \\
\hline $\begin{array}{l}\text { Anaemia controls III } \\
\quad(n=5)\end{array}$ & $\begin{array}{r}24 \cdot 4 \\
\pm 8 \cdot 1\end{array}$ & $\begin{array}{r}54 \cdot 5 \\
\pm 7 \cdot 6\end{array}$ & $\begin{array}{l}161 \cdot 7 \\
\pm 4 \cdot 8\end{array}$ & $\begin{array}{r}25 \cdot 6 \\
\pm 1 \cdot 8\end{array}$ & $\begin{array}{r}48 \cdot 1 \\
\pm .6 \cdot 6\end{array}$ & $\begin{array}{r}7 \cdot 4 \\
\pm 1 \cdot 0\end{array}$ \\
\hline
\end{tabular}

Significant differences: ${ }^{* * *} \mathrm{P}<0.001$

TABLE 2

Responses to Submaximal Exercise expressed in Terms of OXygen Intake at a Work Load of

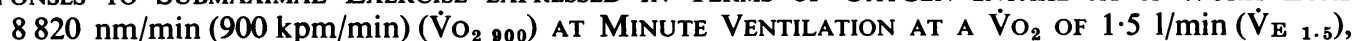
Cardiac Frequency at A $\dot{V}_{2}$ of $1.51 / \mathrm{min}\left(\mathrm{f}_{\mathrm{H}_{1.5}}\right)$ and Predicted Maximum Aerobic Power $\left(\dot{\mathrm{Vo}}_{2} \max \right)$

\begin{tabular}{|c|c|c|c|c|c|}
\hline Group & & $\begin{array}{l}\dot{V O}_{2} 900 \\
(1 / \mathrm{min})\end{array}$ & $\begin{array}{l}\dot{V} E_{1: 5} \\
(1 / \min )\end{array}$ & $\begin{array}{c}\mathbf{f}_{\mathrm{H}_{1} \cdot \mathbf{5}} \\
\text { (beats/min) }\end{array}$ & $\begin{array}{l}\dot{\mathrm{V}} \mathrm{O}_{2 \max } \\
(1 / \mathrm{min})\end{array}$ \\
\hline $\begin{array}{c}\text { Test subjects } I \\
(n=8)\end{array}$ & $\begin{array}{l}\cdots \\
\cdots\end{array}$ & $\begin{array}{r}2 \cdot 06 \\
\pm 0 \cdot 16\end{array}$ & $\begin{array}{r}54 \cdot 5 \\
\pm 14 \cdot 7\end{array}$ & $\begin{array}{l}159 \\
\pm 14 \cdot 7\end{array}$ & $\begin{array}{r}2.05 \\
\pm 0 \cdot 32\end{array}$ \\
\hline $\begin{array}{l}\text { Normal controls II } \\
(n=9) \quad \ldots\end{array}$ & $\begin{array}{l}\ldots \\
\cdots\end{array}$ & $\begin{array}{r}2.06 \\
\pm 0 \cdot 16\end{array}$ & $\begin{array}{r}45 \cdot 2 \\
\pm 7 \cdot 4\end{array}$ & $\begin{array}{l}136 * * 1,111 \\
\pm 12\end{array}$ & $\begin{aligned} & 2 \cdot 54 * \mathrm{I}, \mathrm{II} \\
\pm & 0 \cdot 41\end{aligned}$ \\
\hline $\begin{array}{l}\text { Anaemia controls III } \\
(n=5)\end{array}$ & $\begin{array}{l}\cdots \\
\cdots\end{array}$ & $\begin{array}{r}2.05 \\
\pm 0.08\end{array}$ & $\begin{array}{r}52 \cdot 8 \\
\pm 4 \cdot 4\end{array}$ & $\begin{array}{r}165 \\
\pm 14\end{array}$ & $\begin{array}{r}1.95 \\
\pm 0.19\end{array}$ \\
\hline
\end{tabular}

Significant differences: ${ }^{*} P<0.05 ;{ }^{* *} P<0.01$ 
TABLE 3

Effects of Treatment on Physical Characteristics and Haemoglobin Concentration

\begin{tabular}{|c|c|c|c|c|c|}
\hline \multicolumn{2}{|l|}{ Group } & $\begin{array}{c}W t \\
(k g)\end{array}$ & $\sum_{(m m)} s f f$ & $\begin{array}{c}L B M \\
(k g)\end{array}$ & $\underset{(\mathrm{g} / 100 \mathrm{ml})}{\mathrm{Hb}}$ \\
\hline $\begin{array}{l}\text { Test subjects I } \\
\quad(\mathrm{n}=8)\end{array}$ & . & $+2 \cdot 24$ & $+2 \cdot 54$ & $+2 \cdot 67$ & $+5 \cdot 6^{* * *} \mathrm{II}, \mathrm{III}$ \\
\hline $\begin{array}{l}\text { Normal controls II } \\
(n=9)\end{array}$ & .. & -0.14 & $+1 \cdot 31$ & -0.41 & +0.4 \\
\hline $\begin{array}{l}\text { Anaemic controls III } \\
(n=5)\end{array}$ & .. & +0.50 & $-6.06 * \mathrm{I}, \mathrm{II}$ & +1.97 & 0.5 \\
\hline
\end{tabular}

Significant differences-see Tables 1 and 2

corresponding increase in predicted $\dot{\mathrm{V}} \mathrm{o}_{2} \max$ of $+530 \mathrm{ml} / \mathrm{min}(26 \% ; \mathrm{P}<0.01)$ in test subjects compared to $+70 \mathrm{ml} / \mathrm{min}$ and $+150 \mathrm{ml} / \mathrm{min}$ in the other two groups respectively.

There was a non-significant increase in $\mathrm{Vo}_{2} 900$ of $+150 \mathrm{ml} / \mathrm{min}$ common to all three groups; $\dot{\mathbf{V}}_{\mathbf{E}_{1.5}}$ was reduced $(-6.21 / \mathrm{min})$ in the test subjects, remained constant in the normal controls, and increased slightly $(+1.8 \mathrm{l} / \mathrm{min})$ in the anaemic subjects who did not receive treatment. None of the latter changes reached acceptable levels of significance (Table 4).

Body dimensions remained the same in groups I and II. In the anaemic subjects who did not receive treatment (group III) there was a significant mean decrease of $6.1 \mathrm{~mm}$ in skinfold thickness $(P<0.05)$.

\section{Discussion}

The results confirm our previous findings (Davies et al., 1973) that anaemia $(\mathrm{Hb}<8.5 \mathrm{~g} / 100 \mathrm{ml})$ gives rise to increased cardiac frequency for a given $\mathrm{Vo}_{2}$ without a concomitant change in either the minute ventilation or the $\mathrm{O}_{2}$ cost of work during submaximal exercise (Table 2). At higher levels of work anaemia results in a marked reduction in predicted maximum aerobic power output. The data further show that these changes can be reversed by approximately three months of daily oral iron therapy. These results confirm the findings of Backman (1961) and Duke and Abelmann (1969) at rest and the relevant observations of Andersen and Barkve (1970) in exercise, but they are at variance with the work of Beutler et al. (1960) and Cotes et al. (1972). However, both these latter studies are difficult to interpret from the treatment point of view. Beutler and his co-workers (1960) studied only four 'anaemic' patients, two of whom had $\mathrm{Hb}$ concentrations in excess of $12 \mathrm{~g} / 100 \mathrm{ml}$ before treatment was given, and Cotes and his colleagues were unable to demonstrate any differences between their test subjects and controls before treatment was started. In our experiment we took four major precautions: (1) we tried to ensure that our subjects were familiar with and habituated to the work (Davies et al., 1970) so that the confounding influence of short-term changes in the responses to exercise due to increased familiarity with the test procedures was minimized; (2) we attempted to study our subjects over the complete range of their work capacity up to and occasionally including maximum levels of work in order to minimize the large intra-subject variation in the

TABLE 4

EFFeCts of Treatment on Responses to EXERCISE

\begin{tabular}{|c|c|c|c|c|c|}
\hline Group & & $\begin{array}{l}\dot{\mathrm{V} \mathrm{O}_{2}} 100 \\
(\mathrm{l} / \mathrm{min})\end{array}$ & $\underset{(1 / \mathrm{min})}{\dot{\mathrm{V}}_{\mathbf{E}_{1} \cdot 5}}$ & $\underset{\text { (beats/min) }}{\mathrm{f}_{\mathrm{H}} \mathrm{1}_{\mathrm{5}}}$ & $\begin{array}{l}\dot{\mathrm{V}}_{2 \max } \\
(1 / \mathrm{min})\end{array}$ \\
\hline $\begin{array}{l}\text { Test subjects I } \\
\quad(n=8)\end{array}$ & . & $+0 \cdot 15$ & $-6 \cdot 20$ & $-23^{* * *}$ II & $+0.53^{* * *} \mathrm{II}$ \\
\hline $\begin{array}{l}\text { Normal controls II } \ldots \\
(n=9)\end{array}$ & $\cdots$ & $+0 \cdot 16$ & -0.04 & -1 & +0.07 \\
\hline $\begin{array}{l}\text { Anaemic controls III } \\
(n=5)\end{array}$ & $\cdots$ & +0.15 & +1.80 & -7 & +0.15 \\
\hline
\end{tabular}

Significant differences-see Tables 1 and 2 
prediction of $\dot{\mathrm{V}}_{2} \max$ which occurs when using the $\dot{\mathrm{VO}}_{2} / \mathrm{f}_{\mathrm{H}}$ relationship (Davies, 1968); (3) we supervised the daily taking of the oral iron tablets (this is important in Africa where climate greatly affects the condition of the tablets and where the general population is unused to taking tablets); and (4) we encouraged all our test and control subjects to continue their normal daily (industrial) tasks during the period of the treatment. However, it is unlikely that (1) contributes significantly to the differences we have found between the present study and that of Cotes et al., since in both investigations control subjects were used and any differences due to habituation or learning in the exercise test would presumably be reflected equally in the anaemic, normal and control subjects. Equally, (3) is unlikely to be a relevant factor to the two investigations because in European countries the climate is less harsh and the general population more readily accept the idea of taking tablets or pills for preventive as well as curative purposes. The difficulties of persuading Africans to take tablets and accept treatment when they have no visible or outward signs of illness is underlined by the present study and suggests that this may be an important problem which must be overcome if effective treatment is to be given to African populations on a community basis. Although we were aware of the problem and took the precautions outlined, nevertheless 13 of the original 30 subjects $(43 \%)$ failed either to complete or to begin our course of treatment.

This leaves precautions (1) and (2), and we feel that these two factors undoubtedly had some influence on our results. First, as we have shown previously (Davies et al., 1973), it is only at higher levels of work that the differences between anaemic and non-anaemic subjects become readily apparent. This may have enabled us to demonstrate clear differences in the test and control groups initially and show the effects of treatment more clearly. Secondly, measurements on two severely anaemic patients undergoing treatment in hospital (Davies and van Haaren, unpublished observations) did not demonstrate any significant improvement in their responses to exercise despite increases of approximately $50 \%$ and $100 \%$ in circulating haemoglobin concentration. It would appear that in these patients the potential for exercise had been restored, but their actual work performance had remained unaltered. This puts the question of habitual levels of activity into sharp focus in the treatment of anaemia. The fact that our subjects were leading 'normal' lives, performing everyday tasks, and not confined to hospital wards may account in part for the large changes in physiological function we have been able to demonstrate.

Clearly, the responses to different severities of test exercise in anaemic subjects and the effects of habitual activity combined with therapy are areas for future studies. The results of this investigation do, however, clearly demonstrate that the debilitating effects of anaemia can be reversed by appropriate treatment in subjects who continue to perform their normal daily work.

This finding has an important bearing on a developing country, such as Tanzania, where iron deficiency is endemic (Figure) and where social and economic development depend on human labour. Provided the problems of supervision can be overcome to ensure that the iron tablets are taken regularly over a period of time and workers are encouraged to remain or become more active, then a serious loss of work output and reduced productivity (Davies, 1973) which is associated with anaemia, may be avoided at minimal cost to the occupational health service and the community.

We wish to thank Mr. David Mbelwa for technical assistance and the medical assistants in charge of dispensaries at various factories in Dar es Salaam for their cooperation and interest in the study. We would also like to thank Mr. A. J. Sargeant for invaluable assistance with the analysis of the data.

\section{References}

Andersen, H. T., and Barkve, H. (1970). Iron deficiency and muscular work performance. Scandinavian Journal of Clinical and Laboratory Investigation, 25, Supplement 114, pp. 3-62.

Backman, H. (1961). Circulatory studies in slowly developing anaemias. Scandinavian Journal of Clinical and Laboratory Investigation, 13, Supplement 57.

Beutler, E., Larsh, S., and Tanzi, F. (1960). Iron enzymes in iron deficiency. VII. Oxygen consumption measurements in iron-deficient subjects. American Journal of the Medical Sciences, 239, 759-765.

Brannon, E. S., Merrill, A. J., Warren, J. V., and Stead, E. A. (1945). Cardiac output in patients with chronic anemia as measured by the technique of right atrial catheterization. Journal of Clinical Investigation, 24, 332-336.

Cotes, J. E., Dabbs, J. M., Elwood, P. C., Hall, A. M., McDonald, A., and Saunders, M. J. (1972). Iron deficiency anaemia; its effect on transfer factor for the lung (diffusing capacity) and ventilation and cardiac frequency during submaximal exercise. Clinical Science, 42, 325-335.

- Davies, C. T. M., Edholm, O. G., Healy, M. J. R., and Tanner, J. M. (1969). Factors relating to the aerobic capacity of $\mathbf{4 6}$ healthy British males and females ages 18-28 years. Proceedings of the Royal Society, B 174, 91-114.

Davies, C. T. M. (1968). Limitations to the prediction of maximum oxygen intake from icardiac frequency measurements. Journal of Applied Physiology, 24, 700-706. (1973). Relationship of maximum aerobic power output to productivity and absenteeism of East African sugar cane workers. British Journal of Industrial Medicine, 30, 146-154.

, Chukweumeka, A. C., and van Haaren, J. P. M. (1973). Iron deficiency anaemia: its effect on maximum aerobic power and responses to exercise of African males, aged 17-40 years. Clinical Science, 44, 555-562. 
$\longrightarrow$, and van Haaren, J. P. M. (1973). Anaemia: effect of therapy on responses to exercise. Journal of Physiology, 227, 36-37P.

, Tuxworth, W., and Young, J. M. (1970). Physiological effects of repeated exercise. Clinical Science, 39, 247-258.

Duke, M., and Abelmann, W. K. (1969). The hemodynamic response to chronic anemia. Circulation, 39, 503-515.

Durnin, J. V. G. A., and Rahaman, M. M. (1967). The assessment of the amount of fat in the human body from measurements of skinfold thickness. British Journal of Nutrition, 21, 681-689.

Ojikutu, R. O., Fox, R. H., Davies, C. T. M., and Davies, T. W. (1972). Heat and exercise tolerance of rural and urban groups in Nigeria. In Proceedings of the International Conference on the Human Biology of Environmental Change. Malawi, 1971. I.B.P. London, pp. 132-144.

Passmore, R., and Draper, M. H. (1963). In 'Energy
Metabolism' in Newer Methods of Nutritional Biochemistry, edited by A. A. Albanese. New York, Academic Press.

Roy, S. B., Bhatia, M. L., Mathur, V. S., and Virmani, S. (1963). Hemodynamic effects of chronic severe anemia. Circulation, 28, 346-356.

Sproule, B. J., Mitchell, J. H., and Miller, W. F. (1960). Cardiopulmonary physiological responses to heavy exercise in patients with anemia. Journal of Clinical Investigation, 39, 378-388.

Weir, J. B. de V. (1949). New methods for calculating metabolic rate with special reference to protein metabolism. Journal of Physiology, 109, 1-9.

World Health Organization (1959). Iron deficiency anaemia. Technical report series No.182. WHO, Geneva.

Received for publication January 18, 1973

Accepted for publication April 30, 1973 